\section{AKTSAR}

ISSN 2622-5255 (online)

ISSN 2622-2345 (cetak)

\title{
Diskursus Akuntansi Zakat: Evaluasi Praktis Laporan Keuangan Lazisnu Kabupaten Kudus
}

\author{
Jadzil Baihaqi \\ IAIN Kudus \\ jadzilbaihaqi@stainkudus.ac.id
}

\begin{abstract}
This research aims to identify and explain application about the implementation of PSAK 109 Zakat Accounting to financial reports of Zakat Management. The method used is a case study of LAZISNU Kudus by analyzing the 2017 financial statements and by interviewing the manager. This study finds that, in general, financial reports of LAZISNU Kudus are not in accordance to PSAK 109 because there are two incompatibilities. First, there are only two elements of the five elements in the financial statements, that are the Statement of Changes in Fund and the Statement of Cash Flow. Secondly, Amil funds are not properly recognized and presented, because they were not separated from zakat funds and infaq/shadaqah funds.
\end{abstract}

Keywords: Zakat Accounting; Financial Reports; Management of Zakat 


\begin{abstract}
ABSTRAK
Penelitian ini bertujuan untuk mengetahui dan menjelaskan penerapan PSAK No. 109 tentang Akuntansi Zakat atas laporan keuangan pengelola zakat. Metode yang digunakan adalah studi kasus di LAZISNU Kabupaten Kudus dengan menganalisis Laporan Keuangan Tahun 2017 dan melakukan wawancara dengan pengurus. Peneliti menemukan bahwa pelaporan keuangan LAZISNU Kabupaten Kudus secara umum belum sesuai dengan PSAK No. 109. Peneliti menemukan adanya ketidaksesuaian dalam dua hal. Pertama, hanya ada dua unsur dari lima unsur laporan keuangan pengelolaan zakat, yaitu Laporan Perubahan Dana dan Laporan Arus Kas. Kedua, Dana Amil tidak diakui dan disajikan secara tepat, yaitu tidak dipisahkan dari dana zakat dan dana infak/sedekah.
\end{abstract}

Kata kunci: Akuntansi Zakat, Laporan Keuangan, Lembaga Amil Zakat

\title{
PENDAHULUAN
}

Zakat saat ini telah mengambil perhatian banyak kalangan. Hal ini dikarenakan zakat dipandang dapat membantu menyelesaikan masalah kemiskinan, peningkatan kesejahteraan, dan mengurangi kesenjangan ekonomi di masyarakat. Fakta menunjukkan bahwa pada tahun 2016 BAZNAS berhasil mengumpulkan zakat (termasuk infak, sedekah, dan dana sosial keagamaan lainnya) yang nilainya mencapai Rp 5 Triliun, naik 37\% dari tahun 2015 yang terkumpul sebesar Rp 3,6 Triliun (BAZNAS, 2017). Tren penerimaan zakat diprediksi akan terus meningkat seiring dengan kesadaran masyarakat untuk membayar zakat.

Melihat potensi zakat yang sangat besar ini, pemerintah telah mengesahkan UU No. 23 Tahun 2011 tentang Pengelolaan Zakat yang menyempurnakan dan menggantikan UU No. 38 Tahun 1999. Salah satu poin dalam Pasal 2 UU No. 23 Tahun 2011 menyebutkan pengelolaan zakat berasaskan akuntabilitas. Dalam sudut pandang akuntansi, poin ini sangat penting sebagai dasar pengelolaan zakat, melihat nilai zakat yang dikelola sangat besar. Zakat harus dipertanggungjawabkan dengan baik dan transparan.

Salah satu instrument pertanggungjawaban adalah laporan keuangan. Substansi dari laporan keuangan adalah memberikan informasi kepada pihak-pihak yang berkepentingan tentang perubahan sumber daya yang timbul dari aktivitas organisasi. Dalam konteks pengelolaan zakat, informasi yang disediakan berkaitan dengan penghimpunan, pendistribusian, dan pendayagunaan zakat. Laporan keuangan pengelola zakat ini berfungsi sebagai alat pertanggungjawaban (akuntabilitas) dan transparansi pengelolaan keuangan zakat, serta sebagai alat evaluasi kinerja manajerial dan organisasi pengelola zakat (Kustiawan, et al. 2012). 
Dalam penyusunan laporan keuangan, tentu saja harus mengikuti pedoman yang berlaku, supaya laporan keuangan tersebut dapat dibaca oleh semua pihak dan dapat dibandingkan. Mulanya, pengelola zakat dalam membuat laporan keuangan menganut PSAK No. 45 tentang Pelaporan Keuangan Organisasi Nirlaba. Namun setelah IAI mengesahkan PSAK No. 109 tentang Akuntansi Zakat pada tahun 2010, maka pengelola zakat wajib berpedoman pada PSAK No. 109 dalam menyusun laporan keuangan.

Ada dua organisasi pengelola zakat sesuai dengan UU No. 23 Tahun 2011 yang otomatis terikat dengan PSAK No. 109 tentang Akuntansi Zakat. Pertama, Badan Amil Zakat Nasional baik tingkat pusat, regional/provinsi, maupun tingkat kabupaten/kota. BAZNAS merupakan lembaga utama yang ditunjuk pemerintah untuk mengelola zakat secara nasional. Kedua, Lembaga Amil Zakat yang didirikan oleh masyarakat dan telah dikukuhkan oleh pemerintah melalui Kementerian Agama (Mujahidi, 2016). Lembaga Amil Zakat ini mendukung fungsi BAZNAS dalam mengelola zakat. Lembaga Amil Zakat ini ada yang berdiri sendiri dan ada yang berafiliasi dengan organisasi keagamaan/kemasyarakatan seperti Muhammadiyah dan Nahdlatul Ulama.

Penelitian ini mengambil studi kasus pada Lembaga Amil Zakat, Infaq/Shadaqah Nahdlatul Ulama (LAZISNU) Kabupaten Kudus. LAZISNU merupakan Lembaga Amil Zakat (LAZ) yang sudah mendapatkan legalitas dari Kementerian Agama melalui Keputusan Menteri Agama RI Nomor 65 Tahun 2005 tentang Pengukuhan Lembaga Amil Zakat, Infaq dan Shadaqah Nahdlatul Ulama (LAZISNU) sebagai Lembaga Amil Zakat. Alasan penentuan objek penelitian tersebut adalah pertama, sebagian besar masyarakat Kabupaten Kudus adalah jama'ah organisasi Islam Nahdlatul Ulama (NU) sehingga peneliti mengasumsikan pihak yang berkepentingan terhadap laporan keuangan tersebut sangat banyak. Kedua, laporan keuangan LAZISNU Kabupaten Kudus belum pernah diaudit oleh auditor eksternal (akuntan publik). Fenomena yang terjadi di LAZISNU Kabupaten Kudus yang berkaitan dengan laporan keuangan pengelolaan zakat adalah Laporan Keuangan yang disajikan hanya Laporan Perubahan Dana dan Laporan Arus Kas. Hal ini menunjukkan adanya permasalahan dalam praktik akuntansi zakat pada pengelola zakat.

Penelitian ini diharapkan dapat memberikan manfaat kepada pengelola zakat dalam membuat laporan keuangan pengelolaan zakat berdasarkan PSAK No. 109. Pengelola zakat dapat mempertanggungjawabkan pengelolaan zakat secara transparan dan akuntabel, sehingga dapat memunculkan antusiasme masyarakat muslim untuk membayar zakat dan menitipkan zakatnya di Lembaga Amil Zakat.

\section{TINJAUAN LITERATUR}

Zakat merupakan salah satu rukun Islam yang wajib dilaksanakan oleh orang Islam sebagaimana tercantum dalam QS. At Taubah: 103 di bawah ini.

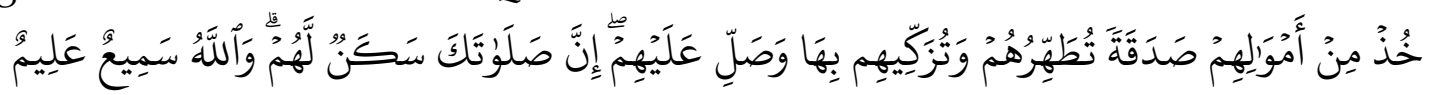

Artinya: Ambillah zakat dari sebagian harta mereka, dengan zakat itu kamu membersihkan dan mensucikan mereka, dan mendoalah untuk mereka. Sesungguhnya doa kamu (menjadi) ketentraman jiwa bagi mereka. Dan Allah SWT mendengar lagi Maha Mengetahui. 
Zakat adalah kadar harga tertentu yang diberikan kepada pihak yang berhak menerimanya dengan beberapa syarat (Rasjid, 1955: 189). Sedangkan dalam UU Nomor 23 Tahun 2011 zakat adalah harta yang wajib dikeluarkan oleh seorang muslim atau badan usaha untuk diberikan kepada yang berhak menerimanya sesuai dengan syariat Islam. Zakat merupakan kewajiban syariah yang harus diserahkan oleh muzaki (orang muslim atau badan usaha yang berkewajiban membayar zakat) kepada mustahik (orang yang berhak menerima zakat), baik melalui amil (pengelola zakat) maupun diberikan secara langsung.

Selain zakat, ada infak/sedekah. Infak/sedekah menurut PSAK No. 109 merupakan harta yang diberikan secara sukarela oleh pemiliknya, baik yang peruntukannya ditentukan maupun tidak ditentukan. Zakat dan infak/sedekah adalah hal yang berbeda secara syariat Islam, sehingga dana zakat dan dana infak/sedekah tersebut juga harus dibedakan. Dampaknya adalah penyajian dalam laporan posisi keuangan juga harus dibedakan, termasuk dana amil.

Pihak yang mengelola zakat dan infak/sedekah adalah amil. Dalam UU Nomor 23 Tahun 2011 dan PSAK No. 109 dijelaskan amil adalah entitas pengelola zakat yang pembentukannya dan atau pengukuhannya diatur berdasarkan ketentuan peraturan perundang-undangan yang dimaksudkan untuk merencanakan, melaksanakan, mengendalikan, melaporkan dan mempertanggungjawabkan pengumpulan, pendistribusian, dan pendayagunaan zakat dan infak/sedekah. Rinciannya adalah (Kustiawan dkk., 2012: 20):

1. Mengumpulkan berarti mengumpulkan zakat, infak/sedekah, dan dana sosial keagamaan lainnya dengan akad muthlaq (tidak ditentukan) atau muqoyyad (ditentukan peruntukannya). Dana dikelompokkan berdasarkan sumbernya.

2. Mendistribusikan berarti membagikan dana yang berhasil dikumpulkan kepada mustahik sesuai dengan syariat Islam dengan akad penyerahan muthlaq. Dana yang didistribusikan akan mengurangi saldo dana sumbernya.

3. Mendayagunakan berarti membagikan dana kepada mustahik dengan akad muthlaq atau muqoyyad yang dilakukan melalui berbagai program/kegiatan yang produktif dan berkesinambungan. Selain itu, amil dapat menginvestasikan dana yang terkumpul apabila sudah tidak ada mustahik yang sangat memerlukan kebutuhan dasarnya.

Menurut UU Nomor 23 Tahun 2011, dalam melaksanakan tugasnya, amil zakat harus berasaskan: syariat Islam, amanah, kemanfaatan, keadilan, kepastian hukum, terintegrasi, dan akuntabilitas. Undang-Undang tersebut mengamanatkan kepada kedua institusi tersebut untuk melaporkan pelaksanaan pengumpulan, pendistribusian, dan pendayagunaan zakat, infak/sedekah, dan dana sosial keagamaan lainnya. Maka menjadi keharusan bagi institusi tersebut untuk membuat laporan keuangan pengelolaan zakat.

Laporan keuangan bertujuan untuk menyediakan informasi yang menyangkut posisi keuangan, kinerja serta perubahan posisi keuangan suatu entitas yang bermanfaat bagi sejumlah besar pengguna dalam pengambilan keputusan ekonomi (IAI, 2016: 7). Selain itu, laporan keuangan juga berfungsi sebagai alat evaluasi kinerja amil zakat. 
Laporan keuangan juga dapat digunakan oleh amil untuk dasar membuat kebijakan dan perencanaan kegiatan tahun selanjutnya.

Dalam menyusun laporan keuangan pengelolaan zakat dan infak/sedekah, amil yang mendapat izin dari regulator/pemerintah wajib berpedoman pada PSAK No. 109 tentang Akuntansi Zakat dan Infak/Sedekah (IAI, 2016: 109.1). Pernyataan ini sudah mengatur bagaimana pengakuan, pengukuran, penyajian, dan pengungkapan transaksi zakat dan infak/sedekah.

\section{Pengakuan dan Pengukuran \\ Penerimaan Zakat}

Penerimaan zakat diakui pada saat kas atau aset nonkas diterima. Zakat yang diterima dari muzaki diakui sebagai penambah dana zakat sebesar jumlah yang diterima (jika dalam bentuk kas) atau nilai wajar (jika dalam bentuk nonkas). Nilai wajar yang digunakan adalah harga pasar. Jika terjadi penurunan nilai aset zakat nonkas, maka jumlah kerugian yang ditanggung diperlakukan sebagai pengurang dana zakat atau pengurang dana amil (jika disebabkan oleh kelalaian amil) (IAI, 2016: 109.2).

\section{Penyaluran Zakat}

Zakat yang disalurkan kepada mustahik termasuk amil diakui sebagai pengurang dana zakat sebesar jumlah yang disalurkan (jika dalam bentuk kas) atau jumlah tercatat (jika dalam bentuk aset nonkas). Bagian dana zakat yang disalurkan untuk amil diakui sebagai penambah dana amil. Dana zakat yang diserahkan kepada mustahik nonamil dengan keharusan untuk mengembalikannya kepada amil, belum diakui sebagai penyaluran zakat. Jika dana zakat yang disalurkan dalam bentuk perolehan aset tetap (aset kelolaan) seperti rumah sakit, sekolah, mobil ambulan, dan fasilitas umum lainnya, maka diakui penyaluran zakat seluruhnya apabila diserahkan kepada pihak lain yang tidak dikendalikan amil. Namun jika aset tetap kelolaan tersebut masih dalam pengendalian amil, maka penyaluran diukur sebesar penyusutan aset tetap tersebut secara bertahap (IAI, 2016: 109.3).

\section{Penerimaan Infak/Sedekah}

Infak/sedekah yang diterima diakui sebagai penambah dana infak/sedekah terikat atau tidak terikat sesuai dengan akad dari pemberi infak/sedekah sebesar jumlah yang diterima (dalam bentuk kas) atau nilai wajar (dalam bentuk nonkas). Infak/sedekah yang diterima dapat berupa kas atau aset nonkas. Aset nonkas dapat berupa aset lancar atau tidak lancar. Nilai wajar yang digunakan adalah harga pasar. Jika terjadi penurunan nilai aset infak/sedekah tidak lancar, maka diakui sebagai pengurang dana infak/sedekah atau pengurang dana amil (jika disebabkan oleh kelalaian amil) (IAI, 2016: 109.4). 


\section{Penyaluran Infak/Sedekah}

Dana infak/sedekah yang disalurkan diakui sebagai pengurang dana infak/sedekah sebesar jumlah yang diserahkan (dalam bentuk kas) atau sebesar nilai tercatat aset yang diserahkan (dalam bentuk aset nonkas). Sedangkan bagian dana infak/sedekah yang disalurkan untuk amil diakui sebagai penambah dana amil. Penyaluran infak/sedekah kepada penerima akhir dalam skema dana bergulir dicatat sebagai piutang infak/sedekah bergulir dan tidak mengurangi dana infak/sedekah (IAI, 2016: 109.4).

\section{Penyajian}

Dana zakat, dana infak/sedekah, dan dana amil disajikan secara terpisah dalam laporan posisi keuangan (IAI, 2016: 109.5).

\section{Pengungkapan}

\section{Zakat}

Amil mengungkapkan hal-hal terkait dengan transaksi zakat, tapi tidak terbatas pada (IAI, 2016: 109.5):

1. Kebijakan penyaluran zakat, seperti penentuan skala prioritas penyaluran, persentase pembagian, dan alasan.

2. Metode penentuan nilai wajar yang digunakan.

3. Rincian jumlah penyaluran dana zakat untuk masing-masing golongan mustahik.

4. Penggunaan dana zakat dalam bentuk aset kelolaan yang masih dikendalikan oleh amil berupa jumlah dan persentase terhadap seluruh penyaluran dana zakat serta alasannya.

5. Hubungan pihak-pihak berelasi antara amil dan mustahik.

\section{Infak/sedekah}

Amil mengungkapkan hal-hal terkait dengan transaksi infak/sedekah, tapi tidak terbatas pada (IAI, 2016: 109.5):

1. Kebijakan penyaluran infak/sedekah, seperti penentuan skala prioritas penyaluran, persentase pembagian, dan alasan.

2. Metode penentuan nilai wajar yang digunakan.

3. Keberadaan dana infak/sedekah yang tidak langsung disalurkan tetapi dikelola dulu dan diungkapkan jumlah dan persentase dari seluruh penerimaan infak/sedekah serta alasannya.

4. Hasil yang diperoleh dari pengelolaan tersebut diungkapkan secara terpisah.

5. Penggunaan dana infak/sedekah menjadi aset kelolaan diungkapkan jumlah dan persentase terhadap seluruh penggunaan dana infak/sedekah serta alasannya.

6. Rincian dana infak/sedekah berdasarkan peruntukannya, terikat dan tidak terikat.

7. Hubungan pihak-pihak berelasi antara amil dan penerima infak/sedekah. 


\section{Unsur-unsur Laporan Keuangan}

Unsur-unsur laporan keuangan amil zakat meliputi (Kustiawan, et al., 2012: 29):

1. Laporan Posisi Keuangan

2. Laporan Perubahan Dana

3. Laporan Perubahan Aset Kelolaan

4. Laporan Arus Kas

5. Catatan atas Laporan Keuangan

\section{Penelitian Terdahulu}

Berdasarkan penelitian terdahulu, sebagian besar temuan penelitian menyatakan bahwa pelaporan keuangan Lembaga Amil Zakat, Infak, Sedekah belum sepenuhnya sesuai dengan PSAK No. 109. Ritonga (2017) dalam penelitiannya pada BAZNAS Sumatera Utara menemukan bahwa Laporan Keuangan BAZNAS Sumatera Utara belum sepenuhnya menerapkan PSAK No. 109. Hal ini terlihat dari tidak adanya pemisahan komponen dana zakat yang berasal dari perorangan atau dari badan/entitas. Selain itu juga tidak ada penjelasan tentang tambahan investasi pada saham Syariah yang berdampak pada selisih penerimaan deviden.

Shahnaz (2016) yang melakukan penelitian pada BAZNAS Sulawesi Utara menemukan hal yang sama. Laporan Keuangan BAZNAS Sulawesi Utara belum mengacu pada PSAK No. 109. Laporan keuangan yang disajikan hanya berupa laporan pemasukan dan pendistribusian dana. Selain itu, penerimaan zakat, infak, sedekah belum dipisahkan sesuai dengan golongannya.

Mujahidi (2016) dalam penelitiannya di Baitul Maal Hidayatullah Cabang Malang juga menemukan bahwa PSAK No. 109 belum sepenuhnya diterapkan dalam penyusunan Laporan Keuangan. BMH Hidayatullah Cabang Malang hanya menyajikan Laporan Posisi Keuangan, Laporan Sumber dan Penggunaan Zakat, dan Laporan Sumber dan Penggunaan Infak. Selain itu, dalam Laporan Posisi Keuangan belum ada pemisahan dana zakat, dana infak, dana wakaf, dan dana nonhalal.

Fitria (2013) dalam penelitiannya pada Badan Amil Zakat Kota Pekanbaru menyimpulkan bahwa Badan Amil Zakat Kota Pekanbaru dalam menyajikan laporan keuangan telah sesuai dengan PSAK No. 109, namun belum membuat laporan keuangan dengan lengkap.

Penelitian yang sudah dilakukan tersebut menjelaskan praktik akuntansi zakat di beberapa daerah. Penelitian ini berusaha melihat praktik akuntansi zakat di daerah lain supaya dapat menambah referensi yang menjelaskan praktik akuntansi zakat di Indonesia secara umum.

\section{METODE PENELITIAN}

Penelitian ini termasuk dalam penelitian lapangan (field research) yang dilakukan pada sebuah organisasi masyarakat atau sosial, yakni LAZISNU Kabupaten Kudus. Penelitian ini termasuk ke dalam jenis penelitian kualitatif. Penelitian ini dimaksudkan untuk memahami fenomena tentang praktik penyusunan laporan keuangan pada 
Lembaga Amil Zakat berdasarkan PSAK No. 109 yang menarik perhatian peneliti untuk melakukan penelitian secara mendalam. Adapun pendekatan pada penelitian ini adalah pendekatan deskriptif, yaitu membandingkan praktik dengan teori yang ada kemudian menarik kesimpulan.

Sumber data dalam penelitian ini ada dua, yaitu data primer dan data sekunder. Data primer berupa prosedur dan kebijakan pengelolaan zakat serta fungsi manajemennya. Data primer dikumpulkan dengan observasi dan wawancara kepada pengurus dan manajemen LAZISNU Kabupaten Kudus. Wawancara dilakukan kepada Ketua Pengurus (Bapak Suyanto) dan staf administrasi (Saudara Nafis). Data sekunder berupa laporan keuangan dan dokumen lain yang dibutuhkan. Data sekunder diperoleh dengan teknik dokumentasi, yaitu mengumpulkan dokumen-dokumen yang terkait dengan penelitian ini.

Analisis data kualitatif dilakukan secara induktif, yaitu dimulai dari fakta empiris kemudian dianalisis dan disimpulkan. Peneliti melakukan penelitian pendahuluan untuk melihat ada masalah atau tidak. Fakta empiris ditemukan bahwa secara sekilas laporan keuangan LAZISNU Kabupaten Kudus tidak lengkap, hanya Laporan Perubahan Dana dan Laporan Arus Kas. Kemudian dari temuan ini, peneliti menganalisis dengan membandingkan laporan keuangan tersebut dengan PSAK No. 109 dan melakukan wawancara dengan pengurus dan staf untuk melakukan konfirmasi.

\section{HASIL DAN PEMBAHASAN}

Hasil penelitian ini dipaparkan berdasarkan pengakuan dan pengukuran, pencatatan, penyajian, dan pengungkapan.

\section{Pengakuan dan Pengukuran}

Pengakuan penerimaan dan penyaluran zakat dan infak/sedekah yang dilakukan oleh LAZISNU Kabupaten Kudus belum semua sesuai dengan PSAK No. 109. Dalam hal pengakuan penerimaan dan penyaluran zakat dan infak/sedekah telah sesuai dengan PSAK No. 109. Pada saat ada penerimaan zakat, atau infak/sedekah langsung diakui sebagai penambah dana zakat, atau infak/sedekah. Zakat yang disalurkan kepada mstahik diakui sebagai pengurang dana zakat. Sedangkan infak/sedekah yang disalurkan diakui sebagai pengurang dana infak/sedekah. Pengukuran zakat dan infak/sedekah yang dilakukan oleh LAZISNU Kabupaten Kudus tidak ada kendala, karena dalam tahun 2017 LAZISNU Kabupaten Kudus tidak menerima aset nonkas. Jadi pengukuran yang dilakukan sesuai dengan jumlah uang yang diterima atau disalurkan.

Dalam hal penerimaan dan penggunaan dana amil, LAZISNU Kabupaten Kudus belum mengakui adanya dana amil. Seluruh biaya operasional mengambil dana infak/sedekah secara langsung. Hal ini tidak sesuai dengan PSAK No. 109 yang mewajibkan adanya pemisahan dana zakat, dana infak/sedekah, maupun dana amil. Pengurus menyatakan bahwa LAZISNU Kabupaten Kudus memang tidak mengambil bagian dari zakat untuk amil. Bapak Suyanto menyatakan: 
“...LAZISNU Kabupaten Kudus memang tidak mengambil bagian amil dari zakat. Seluruh biaya operasional diambilkan dari infak/sedekah. Ketika saya sowan kepada KH. Arifin Fanani untuk meminta kesediaan beliau menjadi Dewan Syariah, beliau bersedia dengan syarat pengelola harus mengikuti Fiqih yang beliau anut. Amil tidak boleh mengambil hak atas zakat yang diterima. Seluruh penerimaan zakat harus diberikan kepada yang berhak kecuali Amil. Kemudian saya menyanggupinya dan saya berjanji tidak mengambil hak amil atas zakat yang diterima."

Hal ini kemudian dimaknai tidak ada dana amil. Padahal dana amil tidak saja berasal dari zakat, melainkan bisa dari infak/sedekah atau penerimaan dana halal lainnya. Menurut syariat Islam dan PSAK No. 109 untuk operasional amil bisa mengambil haknya dari zakat, infak/sedekah, hibah, dan dana sosial keagamaan lainnya. Sehingga untuk menjalankan aktivitas operasional amil menggunakan dana amil sendiri dan bagian amil didapatkan dari zakat, infak/sedekah, hibah dan dana sosial keagamaan lainnya.

\section{Pencatatan}

Pencatatan yang dilakukan oleh LAZISNU Kabupaten Kudus tahun 2017 seluruhnya menganut basis kas. Basis kas digunakan untuk mencatat penerimaan dan penyaluran zakat dan infak/sedekah. Saat ada muzaki membayar zakatnya melalui LAZISNU Kabupaten Kudus, amil langsung mencatat sebagai penerimaan zakat dan memberikan bukti setoran zakat kepada muzaki. Sebaliknya ketika amil menyalurkan zakat kepada mustahik, amil langsung mencatat sebagai penyaluran zakat. Begitu juga dengan infak/sedekah mendapat perlakuan yang sama dengan zakat.

\section{Penyajian}

Penyajian laporan keuangan pengelolaan zakat, infak/sedekah oleh LAZISNU Kabupaten Kudus belum seluruhnya dilakukan. LAZISNU Kabupaten Kudus hanya menyajikan Laporan Perubahan Dana dan Laporan Arus Kas, sedangkan Laporan Posisi Keuangan dan Catatan Atas Laporan Keuangan belum disajikan. Laporan Perubahan Aset Kelolaan tidak dibuat karena LAZISNU Kabupaten Kudus tidak memiliki Aset Kelolaan. Saldo dana zakat dan dana infak/sedekah sudah dipisah sesuai dengan golongannya dan disajikan pada bagian Saldo Dana. Saldo dana amil tidak muncul dikarenakan LAZISNU Kabupaten Kudus tidak mengakui adanya dana amil sebagaimana telah dijelaskan pada bagian pengakuan dan pengukuran di atas.

\section{Pengungkapan}

LAZISNU Kabupaten Kudus belum seluruhnya melakukan pengungkapan sesuai dengan PSAK No. 109. Hal ini terlihat dari tidak adanya Catatan Atas Laporan Keuangan. Dalam laporan yang diterbitkan tidak mengungkapkan kebijakan penyaluran zakat dan infak/sedekah, serta persentase bagian dari amil. Sedangkan penyaluran zakat telah dirinci sesuai dengan masing-masing golongan mustahik. Penyaluran infak/sedekah juga telah dirinci peruntukannya, terikat atau tidak terikat. 


\section{Pembahasan}

Perlakuan akuntansi zakat pada LAZISNU Kabupaten Kudus secara umum belum sepenuhnya sesuai dengan PSAK No. 109. Ada dua temuan ketidaksesuaian penerapan PSAK No. 109, yaitu: pertama, hanya ada dua unsur dari lima unsur laporan keuangan pengelolaan zakat, yaitu Laporan Perubahan Dana dan Laporan Arus Kas. Dari kedua laporan tersebut juga tidak sepenuhnya sesuai dengan PSAK No. 109. Pada Laporan Perubahan Dana tidak didapatkan dana amil sebagaimana telah dijelaskan di atas. Beban-beban operasional diakui sebagai pengurang dana infak/sedekah. Sedangkan pada Laporan Arus Kas masih jadi satu dan belum dirinci masing-masing arus kas dari aktivitas operasional, investasi dan pendanaan.

Kedua, Dana Amil tidak diakui dan disajikan secara tepat oleh LAZISNU Kabupaten Kudus. Dana amil tidak dipisahkan dari dana zakat atau dana infak/sedekah. Walaupun LAZISNU Kabupaten Kudus tidak mengambil bagian amil dari zakat, seharusnya dana amil dari bagian infak/sedekah tetap diungkapkan dan disajikan supaya terlihat jelas dan tepat saldo dana zakat, dana infak/sedekah, dan dana amil sesuai dengan PSAK No. 109.

Laporan Keuangan yang sesuai dengan PSAK No. 109 di jabarkan sebagai berikut (Laporan Keuangan yang utuh disajikan dalam Lampiran):

\section{Laporan Posisi Keuangan}

Laporan Posisi Keuangan LAZISNU Kabupaten Kudus per 31 Desember 2018 terdiri dari Aset dan Saldo Dana yang bernilai Rp 66.349.663. LAZISNU Kabupaten Kudus tidak memiliki akun Liabilitas karena tidak memiliki kewajiban kepada siapapun. Aset yang dimiliki berupa Kas dan Setara Kas senilai Rp 65.349.663, serta ada Piutag Dana Infak/Sedekah kepada NU Care senilai Rp 1.000.000. Saldo Dana terdiri dari Saldo Dana Zakat senilai Rp 11.588.000, Saldo Dana Infak/sedekah senilai Rp 48.114.988, dan Saldo Dana Amil senilai Rp 6.646.675.

\section{Laporan Perubahan Dana}

Laporan Perubahan Dana berisi tentang penerimaan dan penyaluran/penggunaan dana, baik dari zakat, infak/sedekah, maupun dana amil secara terpisah. Selisih dari penerimaan dan penyaluran menjadi saldo dana. Penerimaan zakat, seluruhnya berasal dari penerimaan zakat mal senilai Rp 130.520.000. Sedangkan penyalurannya diberikan kepada mustahik yaitu fakir-miskin dan ibnu sabil melalui program penyaluran langsung senilai Rp 96.432 .000 dan program produktif senilai Rp 22.500.000. Sehingga saldo akhir dana zakat adalah Rp 11.588.000.

Penerimaan dana infak/sedekah berasal dari infak/sedekah tidak terikat yang jumlahnya Rp 75.152.301. Sumber penerimaan infak/sedekah terdiri dari Badan Usaha, Dropbox, kotak INUK, dan perorangan. Dana infak/sedekah yang disalurkan senilai Rp 88.551.480. Pada tahun sebelumnya saldo dana infak/sedekah sebesar Rp 61.514.167. Sehingga saldo akhir dana infak/sedekah adalah Rp 48.114.988. 
Dana amil bersumber dari bagian atas penerimaan infak/sedekah saja. Bagian amil atas penerimaan infak/sedekah adalah senilai Rp 18.788.075. Operasional Lembaga selama tahun 2017 menghabiskan biaya Rp 12.141.400. Sehingga saldo dana amil yang belum dipakai adalah $\mathrm{Rp}$ 6.646.675.

\section{Laporan Arus Kas}

Laporan Arus Kas berisi arus kas masuk dan keluar atas pengelolaan zakat dan infak/sedekah. Arus kas yang terjadi selama tahun 2017 hanya untuk aktivitas operasional Lembaga. Kas dan setara kas pada akhir periode dari dana zakat sebesar Rp 11.588.000, dari dana infak/sedekah senilai Rp 47.114.988, dan dana amil senilai Rp 6.646.675. Sehingga saldo kas dan setara kas per 31 Desember 2017 adalah senilai Rp 65.349.663.

\section{Catatan Atas Laporan Keuangan}

Catatan atas Laporan Keuangan LAZISNU Kabupaten Kudus berisi tentang pengungkapan atas kebijakan dan informasi tambahan yang perlu disajikan dalam Laporan Keuangan. Laporan ini mengungkapkan tentang hal umum, ikhtisar kebijakan akuntansi signifikan, dan kebijakan akuntansi. Bagian umum menjelaskan informasi pendirian Lembaga, susunan pengurus, dan pernyataan tanggung jawab manajemen atas laporan keuangan. Bab ikhtisar kebijakan akuntansi signifikan berisi pernyataan kepatuhan terhadap standar akuntansi keuangan dan dasar pengukuran dan penyusunan laporan keuangan. Bab kebijakan akuntansi menjelaskan tentang beberapa kebijakan penting terkait dengan bagaimana kebijakan mengakui penerimaan dan penyaluran zakat dan infak/sedekah. Selain itu juga diungkapkan persentase bagian amil atas infak/sedekah dan kebijakan penggunaannya.

\section{SIMPULAN}

Penelitian penerapan Akuntansi Zakat berdasarkan evaluasi praktis Laporan Keuangan Pengelola Zakat menghasilkan simpulan bahwa secara umum LAZISNU Kabupaten Kudus belum sepenuhnya menerapkan PSAK No. 109 dalam membuat Laporan Keuangan pengelolaan zakat dan infak/sedekah. Hal ini didasarkan pada dua temuan, yaitu: pertama, hanya ada dua unsur dari lima unsur laporan keuangan pengelolaan zakat, yaitu Laporan Perubahan Dana dan Laporan Arus Kas. Kedua, Dana Amil tidak diakui dan disajikan secara tepat. Dana amil tidak dipisahkan dari dana zakat dan dana infak/sedekah.

Berdasarkan kesimpulan tersebut, penelitian yang dapat dilakukan berikutnya adalah menganalisis mengapa laporan keuangan pengelolaan zakat tidak sepenuhnya sesuai dengan PSAK No. 109. Kemudian dapat diketahui faktor apa saja yang menjadikan praktik akuntansi zakat tidak berjalan dengan baik. Pada akhirnya dapat diupayakan solusi terbaik untuk mengatasi masalah tersebut sehingga tujuan dari akuntansi zakat dapat tercapai. 


\section{DAFTAR PUSTAKA}

Badan Amil Zakat Nasional (BAZNAS). (2017). Statistik Zakat Nasional 2016. Jakarta: Bagian SIM dan Pelaporan BAZNAS.

Fitria, Nurul. (2013). Analisis Penyusunan Laporan Keuangan Badan Amil Zakat Kota Pekanbaru Menurut PSAK 109. Skripsi. Pekanbaru: UIN Sultan Syarif Kasim.

Ikatan Akuntan Indonesia. (2016). Standar Akuntansi Keuangan Syariah Efektif Per 1 Januari 2017. Jakarta: IAI.

Keputusan Menteri Agama RI Nomor 65 Tahun 2005 tentang Pengukuhan Lembaga Amil Zakat, Infaq dan Shadaqah Nahdlatul Ulama (LAZISNU) sebagai Lembaga Amil Zakat.

Kustiawan, T., Bachtiar, A., Sasmita, D., Andayani, D. R., Sunidja, E., Mahmudi, Ichsan, M. S., Sudarno, P., Muhammad, R., Suprihartini, R., \& Syukur, S. (2012). Pedoman Akuntansi Amil Zakat Panduan Implementasi Penyusunan Laporan Keuangan Berbasis PSAK 109. Jakarta: Forum Zakat (FOZ).

Mujahidi, Khairul. (2016). Analisis Penerapan PSAK 109 dalam Penyusunan Laporan Keuangan pada Lembaga Amil Zakat (Studi Kasus pada Baitulmaal Hidayatullah Cabang Malang). Skripsi. Malang: UIN Maulana Malik Ibrahim.

Peraturan Pemerintah RI Nomor 14 Tahun 2014 tentang Pelaksanaan UU Nomor 23 Tahun 2011 tentang Pengelolaan Zakat.

Rasjid, Sulaiman. (1955). Figh Islam (Edisi 2). Jakarta: Attahirijah Djati

Ritonga, Pandapotan. (2017). Analisis Akuntansi Zakat Berdasarkan PSAK No. 109 pada Badan Amil Zakat Nasional (BAZNAS) Sumatera Utara. KITABAH Vol. 1(1): 1-19.

Shahnaz, Sabrina. (2016). Penerapan PSAK No. 109 tentang Pelaporan Keuangan Akuntansi Zakat, Infaq/Sedekah pada BAZNAS Provinsi Sulawesi Utara. Jurnal Berkala Ilmiah Efisiensi Vol. 16(1): 449-458.

Undang-Undang Nomor 23 Tahun 2011 tentang Pengelolaan Zakat. 